University of Northern Colorado

Scholarship \& Creative Works @ Digital UNC

President's Office

Administration

2006

The Effects of Coupon Promotion on Repeat Visits in Restaurants

Andrew Hale Feinstein

Follow this and additional works at: https://digscholarship.unco.edu/president 


\section{The Effects of Coupon Promotion on Repeat Visits in Restaurants}

\section{Eunha Myung PhD, Deborah Barrash PhD \& Andy Feinstein PhD}

To cite this article: Eunha Myung PhD, Deborah Barrash PhD \& Andy Feinstein PhD (2007) The Effects of Coupon Promotion on Repeat Visits in Restaurants, Journal of Foodservice Business Research, 9:1, 55-75, DOI: 10.1300/J369v09n01_05

To link to this article: https://doi.org/10.1300/J369v09n01_05

曲 Published online: 08 Sep 2008.

Submit your article to this journal $\pi$

LII Article views: 430

Q View related articles $₫$

4 Citing articles: 2 View citing articles 


\title{
The Effects of Coupon Promotion on Repeat Visits in Restaurants
}

\author{
Eunha Myung \\ Deborah Barrash \\ Andy Feinstein
}

\begin{abstract}
Will customers' intention to return to a restaurant increase with coupon promotion? To answer this question, this study examines the hypothetical effects of coupon promotion on return visits to restaurants. Based on a literature review, three hypotheses were developed to test the effect of a coupon, its face value, and a patron's prior dining experience on return intention. The authors found that neither coupon use nor coupon face value contributed to explaining respondents' return intentions. However, repeat customers have a greater likelihood of returning to the restaurant than new customers. The study also showed that the quality of food and service were key indicators of return intention. doi:10.1300/J369v09n01_05 [Article copies available for a fee from The Haworth Document Delivery Service: 1-800-HAWORTH. E-mail address: <docdelivery@ haworthpress.com> Website: <http://www.HaworthPress.com> () 2006 by The Haworth Press, Inc. All rights reserved.]
\end{abstract}

KEYWORDS. Coupon promotion, return visit, coupon face value, restaurant marketing

Eunha Myung, PhD, is Assistant Professor, School of Family, Consumer, and Nutrition Sciences, Northern Illinois University, DeKalb, IL 60115-2854 (E-mail: myunge@ unlv.nevada.edu).

Deborah Barrash, PhD, is Assistant Professor, William F. Harrah College of Hotel Administration, University of Nevada, Las Vegas, 4505 Maryland Parkway, Las Vegas, NV 89154-6022 (E-mail: deborah.barrash@unlv.edu).

Andy Feinstein, PhD, is Associate Professor (E-mail: andyf@unlv.nevada.edu), William F. Harrah College of Hotel Administration, University of Nevada, Las Vegas, 4505 Maryland Parkway, Las Vegas, NV 89154-6022.

Journal of Foodservice Business Research, Vol. 9(1) 2006

Available online at http://jfbr.haworthpress.com

(C) 2006 by The Haworth Press, Inc. All rights reserved. doi:10.1300/J369v09n01_05 


\section{INTRODUCTION}

Coupon promotion is a commonly used sales promotional tool in the restaurant industry (Taylor, 2001; Varadarajan, 1984). It is estimated that restaurants account for $10-15 \%$ of about 6 billion freestanding coupons distributed per year in the United States (Perlik, 2002). In general, coupon promotion is often used to generate a short-term sales increase (Taylor, 2001; Ehrenberg, Hammond, \& Goodhardt, 1994), to increase customer traffic (Perlik, 2002), to attract new customers (Taylor \& LongTolbert, 2002; Varadarajan, 1984), and to encourage repeat purchase of a brand (Krishna \& Shoemaker, 1992). Marketers believe that a coupon is an effective promotional tool in generating a short-term sales increase and attracting new customers, but they still question the long-term effect of coupon promotion on repeat purchase. Marketers also expect that coupon promotion may drive new customers to switch brands, eventually converting them into repeat customers (Ehrenberg et al., 1994). Similarly, restaurateurs hope that new customers who redeem coupons will like the restaurants and will return even without coupons in the future and pay full price for those meals.

To date, extensive research in coupon promotion and its long-term effects have been produced in the consumer goods industry. Despite the heavy utilization of coupon promotion in the restaurant industry, only a few studies (e.g., Taylor \& Long-Tolbert, 2002; Varadarajan, 1984) have examined the effects of coupon promotion in this context. Given the importance of coupon promotion effects in the restaurant industry and the question of repeat purchase, further research is well warranted. The purpose of this study is, therefore, to examine the effects of coupon promotion on return intention to restaurants. Specifically, we would like to determine the likelihood of return visits if a coupon is redeemed and the factors that influence customers to return to restaurants.

\section{LITERATURE REVIEW}

There are two contrasting views regarding the effects of coupon promotion on repeat purchase. The positive perspective of repeat purchase argues that consumers will continue to buy the products after they redeem the coupons even though a coupon for that brand is no longer available (Taylor \& Long-Tolbert, 2002; Shoemaker \& Tibrewala, 1985). 
This is because new customers who have positive experiences with a product may buy the product again and eventually become regular customers. Also, regular customers of a brand regard coupon promotion as a reward (Blattberg \& Neslin, 1990, p. 271), and such a reward encourages them to continue buying the brand.

Operant conditioning theory explains the nature of coupon promotion as a reward that enables the consumer to learn to continue to buy the products (Blattberg \& Neslin, 1990, p. 271). The theory suggests that a reinforced behavior is more likely to be repeated. For example, when a customer receives a coupon from a restaurant at the time of meal purchase, the customer perceives the coupon as a reward, increasing the probability of return to the same restaurant in the future.

In contrast, the negative side argues that repeat purchase in fact declines when the coupon promotion is over. Previous studies have shown that coupons attract new or infrequent customers (Bawa \& Shoemaker, 1987 ) because their primary reason to respond to coupon promotion is economic benefits associated with saving money by using the coupon (Taylor, 2001). When such economic incentive is no longer available, these customers are less likely to buy that product again at regular price.

Dodson, Tybout, and Sternthal (1978) apply the self-perception theory to coupon promotion to explain why repeat purchase rate is low after coupon promotion. They state that if a customer purchases a product under the premise of a deal, it is not clear whether the attraction is due to the product's attributes or the coupon incentive. However, when such incentive (i.e., money savings from a coupon) is removed, the customer recognizes that "an important reason for the previous behavior, the incentive, is no longer present" (p. 74). Therefore, when the incentive is removed, the intention to repurchase the product decreases. If a customer buys a product without incentive, the product attribute is the clear attraction. As a result, he or she will continue to purchase that product. This leads to the first hypothesis:

H1: Coupons reduce the likelihood of customers returning to the restaurant without a coupon.

Face Value: Coupon face value is defined as the "monetary amount that a consumer saves off the selling price when a coupon is used to purchase a product" (Pointer, 2000). Prior studies have shown that there is a positive relationship between the coupon face value and coupon redemption rate (Bawa \& Shoemaker, 1987; Shoemaker \& Tibrewala, 
1985; Irons, Little, \& Klein, 1984). Shoemaker and Tibrewala (1985) conducted a survey to examine a redemption pattern for different face values. They found that customers redeemed higher face value coupons to a greater extent than those of lower value. New and infrequent customers especially showed significantly higher redemption rates for higher face values than regular buyers. This is because higher coupon face value offers non-buyers a monetary incentive to purchase and lessens the risks of purchasing unfamiliar products (Garretson \& Chow, 1999). This logic supports the finding of Dodson, Tybout, and Sternthal (1978); higher coupon face value undermines repeat purchase probabilities. It is suggested that new customers are mainly attracted by the economic incentives with high coupon value, and when such economic reasons to buy the product are no longer available after a coupon promotion is concluded, they may not find any good reasons to buy the product at full price in the future. In Cheong's (1993) study of coupon face value and its influence on repeat purchase rate, his findings support the above notion that economic incentives strongly affect repeat purchase rates: the higher the coupon face value, the lower the price/value perception, and subsequent probability of repeat purchase. Hence the following hypothesis is given:

$\mathrm{H} 2$ : The higher the coupon face value, the lower a customer's return intention.

Prior Dining Experiences: Previous studies state that regular buyers of a brand are more likely to be repeat buyers than non-regular buyers after a coupon promotion has ended (Taylor \& Long-Tolbert, 2002; Taylor, 2001; Bawa \& Shoemaker, 1989; Shoemaker \& Shoaf, 1977). This is because regular buyers are already familiar with the product attributes and have developed quality perceptions of the product from their prior experiences (Taylor \& Long-Tolbert, 2002). This type of coupon promotion, offered as a reward, then encourages current customers to continue to support the brand.

Shoemaker and Shoaf (1977) examined the correlation between past purchases with coupon promotions and those with the regular prices on repeat purchase context. They found that the probability of repeat purchase was significantly higher among those who purchased products at regular prices. In a study of coupon promotions in a quick-service restaurant, Taylor and Long-Tolbert (2002) also found that regular customers with frequent prior purchases continue to visit the restaurant in 
the post-promotion period. In addition, the study suggests that consumers who redeemed a coupon showed 7.5 times higher probability of repeat purchase than consumers who did not redeem a coupon. The authors argue that because of unique characteristics of service experiences (vs. consumer goods purchases) such as the combination of tangible (e.g., food) and intangible (e.g., personalized services) quality of service and the familiarity of food and service in that restaurant, consumers are unlikely to switch restaurants, and are more likely to repeat purchase if they are familiar with such service products. Hence:

H3: After a coupon is redeemed, customers with prior dining experience in a particular restaurant will be more likely to return to that restaurant than those with no prior dining experience.

Food Quality and Service Quality: Consumers evaluate service products differently from consumer goods because of the unique characteristics of service products. For example, when a consumer buys a tangible product in a restaurant, that person does not evaluate just one aspect of the tangible product, but instead evaluates the total service delivery experience-a combination of a tangible product, service, and ambiance as well. This combination of attributes evaluated in a service situation cannot be separated (Bebko, 2000) from the consumer's evaluation of the product he/she purchased in the restaurant. In a study of restaurant selection behavior, Kivela (1997) found that food quality was the most frequently used variable in a restaurant's selection.

This finding is consistent with Lewis's (1981) study that food quality was the most influential characteristic on return visit intention in restaurants. Service quality cannot be stressed enough on customer repeat purchase. Studies have shown that high quality service results in higher repeat purchase (Zeithaml, 2000; Ennew \& Binks, 1996). Therefore, we included food and service quality variables and held them constant while evaluating the effects of prior dining experience and coupon face value on return intention.

\section{METHODOLOGY}

\section{Data Collection Overview}

Self-administered survey data were collected from a convenience sample of undergraduate students who were enrolled in the Hotel 
Management, Food and Beverage Management, and Tourism and Convention Management departments at a state university in the southwest. The surveys were distributed and collected during regularly scheduled class sessions over the course of two one-week periods in the spring and fall of 2005.

Thirty-two different scenarios were developed to measure different conditions of coupons, service quality, food quality, and prior dining experience The prior dining experience variable was manipulated at two levels: prior dining experience and no prior dining experience; food quality was manipulated at two levels: good food quality and poor food quality; service quality was divided into two levels: good service quality and poor service quality; and coupon face value was manipulated at four levels: $50 \%$ discount, $30 \%$ discount, $15 \%$ discount, and no coupon. However, these discount levels were provided to the subjects as dollar amounts off of their $\$ 20$ meal cost: $\$ 10, \$ 6, \$ 3$, and nothing, respectively. Converting the percentage discounts into dollars off kept the respondents from having to calculate the discount percentage into a dollar amount. These levels of manipulation are arrayed in a tree diagram (Figure 1).

The same survey questions were asked regardless of which of the 32 scenarios the respondent was randomly assigned. The survey was four pages in length. The first page of the survey included one of the 32 scenarios and the respondent was asked to imagine themselves in the given scenario before answering the survey questions. The restaurant scenario was developed based on an average check of $\$ 20$ per customer. A total of 900 surveys were distributed and 816 were collected, representing a $91 \%$ response rate. Of the 816 surveys collected, three were eliminated from the analysis because they did not provide complete responses.

\section{Measurement}

The variable use as the dependent variable, likelihood of a return visit, was measured using a seven-point Likert-type scale with anchors ranging from "Not at all likely" (1) to "Very likely" (5). The independent variables used included prior dining experience ("Yes" or "No"), and importance of food quality and service quality. Food and service quality were both measured on a seven-point Likert-type scale with anchors ranging from "Not at all important" (1) to "Very important" (7). The demographic questions asked included age, gender, household 
FIGURE 1. Levels of Testing Conditions

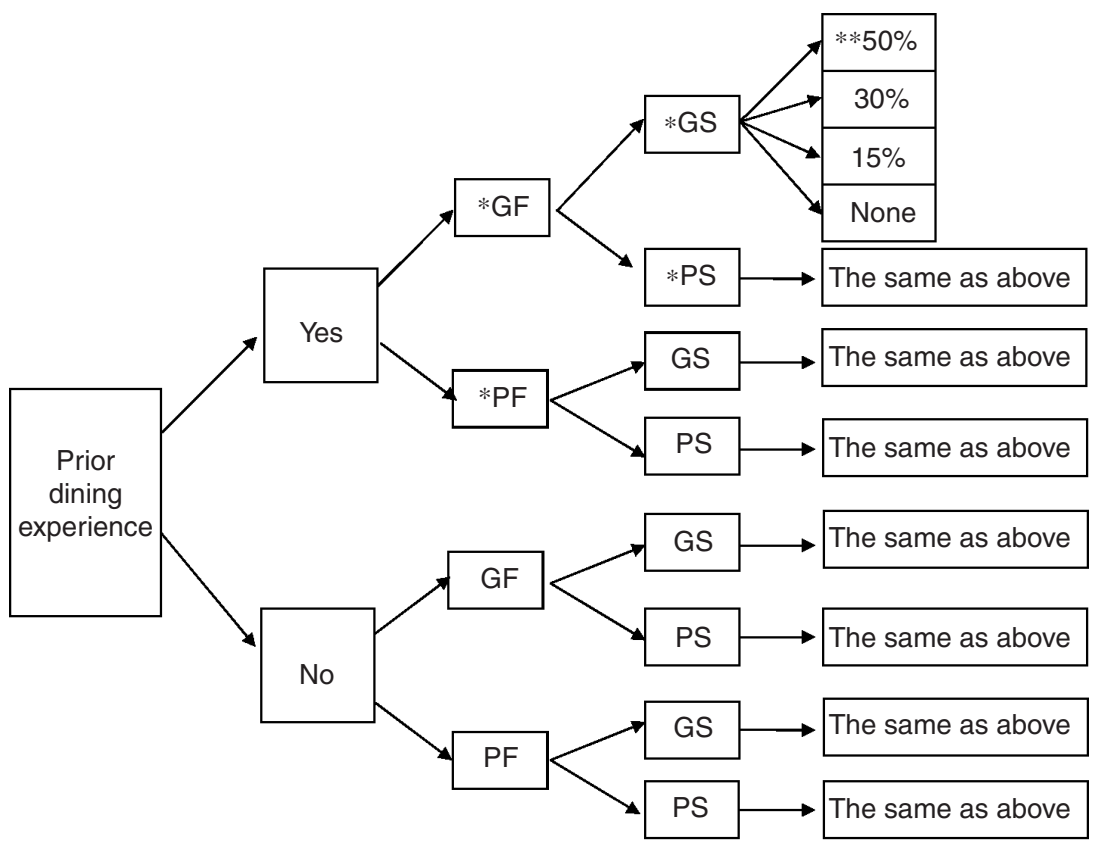

*GS: Good service quality; PS: Poor service quality; GF: Good food quality; PF: Poor food quality ** $50 \%$ : coupon face value $50 \%$ discount; $30 \%$ : coupon face value $30 \%$ discount; $15 \%$ : coupon face value $15 \%$ discount; none: no coupon offered.

income, student status, frequency of dining out, average meal cost of meals eaten away from home, and native language.

\section{RESULTS}

\section{Description of Respondents}

The participants included 374 males (53\%) and 431 females (46\%). The mean age of the respondents was 23 years. The majority $(\mathrm{n}=470$, $57.8 \%$ ) of the respondents spent an average of $\$ 11-\$ 20$ per person for a meal, were full-time students $(\mathrm{n}=724,89.1 \%)$, had annual household incomes of more than $\$ 30,000(\mathrm{n}=286,35.2 \%)$, and dined out two to three times a week $(n=384,47.2 \%)$. Table 1 provides descriptions of the respondents. 
TABLE 1. Description of Respondents

\begin{tabular}{|c|c|c|}
\hline & $\mathbf{n}$ & $\%$ \\
\hline \multicolumn{3}{|l|}{ Age $($ mean $=23$ years old $)$} \\
\hline $18-24$ & 626 & 77.0 \\
\hline $25-29$ & 124 & 15.3 \\
\hline $30-35$ & 30 & 3.7 \\
\hline Over 35 & 23 & 2.8 \\
\hline Missing & 10 & 1.2 \\
\hline \multicolumn{3}{|l|}{ Sex } \\
\hline Male & 374 & 53.0 \\
\hline Female & 431 & 46.0 \\
\hline Missing & 8 & 1.0 \\
\hline \multicolumn{3}{|l|}{ Household income } \\
\hline Less than $\$ 10,000$ & 241 & 29.6 \\
\hline$\$ 11,000-\$ 20,000$ & 129 & 15.9 \\
\hline$\$ 21,000-\$ 30,000$ & 100 & 12.3 \\
\hline More than $\$ 30,000$ & 286 & 35.2 \\
\hline Missing & 57 & 7.0 \\
\hline \multicolumn{3}{|l|}{ Dine out } \\
\hline Less than once a week & 109 & 13.4 \\
\hline Once a week & 187 & 23.0 \\
\hline Twice a week & 205 & 25.2 \\
\hline Three times a week & 179 & 22.0 \\
\hline More than three times a week & 126 & 15.5 \\
\hline Missing & 11 & 0.8 \\
\hline \multicolumn{3}{|l|}{ Average meal cost per person } \\
\hline Less than $\$ 10$ & 125 & 15.3 \\
\hline$\$ 11-\$ 20$ & 470 & 57.8 \\
\hline More than $\$ 20$ & 210 & 25.9 \\
\hline Missing & 8 & 1.0 \\
\hline \multicolumn{3}{|l|}{ Status } \\
\hline Full-time & 724 & 89.1 \\
\hline Part-time & 67 & 8.2 \\
\hline Not a student & 4 & 0.5 \\
\hline Missing & 18 & 2.2 \\
\hline
\end{tabular}

\section{Data Analysis}

\section{Manipulation Checks}

Manipulation checks were conducted to ensure that the manipulating variables were serving their roles. Respondents were asked four questions about the scenario they were given. Each one was tied to one of the independent variables (prior dining, coupon face value, food quality, 
and service quality). Reliability tests were conducted for each of the independent variables. The Cronbach's alphas, inter-item correlations, and $\mathrm{p}$-values are reported in Table 2. Although the alpha values for food quality and service quality are below the minimum acceptable level of 0.70 , this may be due to the fact that the original scenarios only had two levels of distinction ("Good" and "Poor") and the manipulation check asked the respondents to give the level of distinction on a 7-point Likert-type scale. When Pearson's correlation coefficients were calculated for each of these independent variables, they were all over 0.80 $(p=0.000)$, indicating strong reliability in the respondent's understanding of the scenarios.

\section{Correlations}

The correlation coefficients among all independent variables and return intention were calculated (see Table 3 ). A statistically significant relationship between respondents' return intention and whether or not they received a coupon was not found. There was also no relationship based on the face value of the coupon they received. However, a

TABLE 2. Manipulation Checks of Independent Variables

\begin{tabular}{lccc}
\hline $\begin{array}{l}\text { Independent } \\
\text { Variable }\end{array}$ & $\begin{array}{c}\text { Cronbach's } \\
\text { Alpha }\end{array}$ & $\begin{array}{c}\text { Inter-item } \\
\text { Correlation }\end{array}$ & Sig. \\
\hline Prior dining & 0.890 & 0.802 & 0.000 \\
Coupon value & 0.923 & 0.857 & 0.000 \\
Food quality & 0.514 & 0.800 & 0.000 \\
Service quality & 0.499 & 0.824 & 0.000 \\
\hline
\end{tabular}

TABLE 3. Correlation with Return Intention

\begin{tabular}{lclc}
\hline Independent Variable & $\mathbf{r}$ & Sig. & $\mathbf{n}$ \\
\hline Prior dining & 0.165 & $0.000^{*}$ & 810 \\
Coupon value & 0.012 & 0.727 & 810 \\
Coupon Yes/No & 0.007 & 0.846 & 810 \\
Food & 0.522 & $0.000^{\star}$ & 810 \\
Service & 0.413 & $0.000^{*}$ & 810 \\
\hline
\end{tabular}

*Significant at $p<0.0001$ 
statistically significant relationship between return intention and prior dining experience, food quality, and service quality was found.

\section{Coupon and Coupon Face Value Effects on Return Intention}

In order to test the effect of coupon face value on return intention, two general linear models were generated. The first model used a dummy variable (1: with coupon, 0 : no coupon) to represent whether or not a respondent used a coupon (see Table 4). The second model used the coupon face values (see Table 5). Both models also included the three other independent variables (prior dining experience, food quality, and service quality). In both models, there was not a statistically significant main effect for the coupon. Findings indicate that neither coupon use nor coupon face value contributed to explaining respondents' return intentions. In addition, different coupon face values also did not contribute to consumers' return intentions. The average return intention regardless of coupon value ranged from 3.65 to 3.85 on a 7 -point Likert-type scale where $1=$ "Not at

TABLE 4. ANOVA Summary Table for Return Intention with Coupon (CpnYes/ No)

\begin{tabular}{lrrrrl}
\hline Source & \multicolumn{1}{c}{ SS } & df & \multicolumn{1}{c}{ MS } & \multicolumn{1}{c}{ F } & Sig. \\
\hline PriorDine & 38.30 & 1 & 38.30 & 20.19 & $0.000^{* *}$ \\
CpnYes/No & 0.13 & 1 & 0.13 & 0.07 & 0.794 \\
Food & 525.69 & 1 & 525.69 & 277.07 & $0.000^{* *}$ \\
Service & 212.77 & 1 & 212.77 & 112.14 & $0.000^{* *}$ \\
PriorDine * CpnYes/No & 0.18 & 1 & 0.18 & 0.10 & 0.757 \\
PriorDine * Food & 24.45 & 1 & 24.45 & 12.89 & $0.000^{* *}$ \\
CpnYes/No * Food & 11.47 & 1 & 11.47 & 6.05 & $0.014^{*}$ \\
PriorDine * CpnYes/No * Food & 7.61 & 1 & 7.61 & 4.01 & $0.046^{*}$ \\
PriorDine * Service & 0.28 & 1 & 0.28 & 0.15 & 0.703 \\
CpnYes/No * Service & 5.40 & 1 & 5.40 & 2.85 & 0.092 \\
PriorDine * CpnYes/No * Service & 1.33 & 1 & 1.33 & 0.70 & 0.402 \\
Food * Service & 67.19 & 1 & 67.19 & 35.41 & $0.000^{* *}$ \\
PriorDine * Food * Service & 2.45 & 1 & 2.45 & 1.29 & 0.256 \\
CpnYes/No * Food * Service & 1.40 & 1 & 1.40 & 0.74 & 0.390 \\
PriorDine * CpnYes/No * Food * Service & 3.13 & 1 & 3.13 & 1.65 & 0.199 \\
\hline
\end{tabular}

*Significant at $p<0.05$;

${ }^{* \star}$ Significant at $p<0.01$ 
TABLE 5. ANOVA Summary Table for Return Intention with Coupon Face Value (CpnValue)

\begin{tabular}{lrrrrc}
\hline Source & \multicolumn{1}{c}{ SS } & df & MS & \multicolumn{1}{c}{ F } & Sig. \\
\hline PriorDine & 76.95 & 1 & 76.95 & 40.24 & $0.000^{*}$ \\
CpnValue & 3.83 & 3 & 1.28 & 0.67 & 0.572 \\
Food & 856.43 & 1 & 856.43 & 447.83 & $0.000^{*}$ \\
Service & 470.09 & 1 & 470.09 & 245.81 & $0.000^{*}$ \\
PriorDine * CpnValue & 3.02 & 3 & 1.01 & 0.53 & 0.665 \\
PriorDine * Food & 24.07 & 1 & 24.07 & 12.59 & $0.000 *$ \\
CpnValue * Food & 12.68 & 3 & 4.23 & 2.21 & 0.086 \\
PriorDine * CpnValue * Food & 8.58 & 3 & 2.86 & 1.50 & 0.214 \\
PriorDine * Service & 0.00 & 1 & 0.00 & 0.00 & 0.972 \\
CpnValue * Service & 6.50 & 3 & 2.17 & 1.13 & 0.335 \\
PriorDine * CpnValue * Service & 5.90 & 3 & 1.97 & 1.03 & 0.379 \\
Food * Service & 109.61 & 1 & 109.61 & 57.32 & $0.000 *$ \\
PriorDine * Food * Service & 0.88 & 1 & 0.88 & 0.46 & 0.498 \\
CpnValue * Food * Service & 4.01 & 3 & 1.34 & 0.70 & 0.553 \\
PriorDine * CpnValue * Food * Service & 4.68 & 3 & 1.56 & 0.82 & 0.486 \\
\hline
\end{tabular}

*Significant at $p<0.0001$

all likely" and $7=$ "Very likely" (see Table 6). Therefore, the first two hypotheses were not supported.

We also looked at the interaction effects on return intention for both models. In the model with the dummy variable for coupon versus no coupon, significant interaction effects were found between PriorDine $*$ Food $(p<0.0001)$, CpnYes/No $*$ Food $(p<0.05)$, PriorDine $*$ CpnYes/ No $*$ Food $(p<0.05)$, and Food $*$ Service $(p<0.0001)$. In the model which used different face values for the coupon variable, significant interaction effects were found between PriorDine $*$ Food $(p<0.0001)$ and Food $*$ Service $(p<0.0001)$. These findings indicate that consumers with prior dining experience in the restaurant and who utilized a coupon are more likely to return to the restaurant when the food quality is good. To test for multi-collinearity among the independent variables, the correlation coefficients among them were computed. As can be seen in Table 7, none of them were statistically significant.

Profile plots of the independent variables were also created using the coupon redemption (see Figure $2 \mathrm{a}-\mathrm{c}$ ) and coupon face value (see 
TABLE 6. Mean Return Intention

\begin{tabular}{lcc}
\hline & Mean (SD) & Cell Size \\
\hline $\begin{array}{l}\text { Overall } \\
\text { Prior experience }\end{array}$ & $3.75(1.98)$ & 810 \\
$\quad$ Yes & $4.08(1.91)$ & 412 \\
$\quad$ No & $3.42(2.00)$ & 398 \\
Coupon & & \\
$\quad$ None & $3.79(2.16)$ & 113 \\
$\$ 3$ & $3.75(1.88)$ & 229 \\
$\$ 6$ & $3.65(1.97)$ & 234 \\
\$10 & $3.85(2.00)$ & 234 \\
Food & & \\
$\quad$ Good & $4.79(1.82)$ & 406 \\
Poor & $2.72(1.55)$ & 404 \\
Service & & 406 \\
Good & $4.57(2.02)$ & 404 \\
Poor & $2.93(1.56)$ & \\
Food/service & & 202 \\
GF/GS & $6.00(1.32)$ & 204 \\
GF/PS & $3.59(1.41)$ & 204 \\
PF/GS & $3.16(1.56)$ & 200 \\
PF/PS & $2.27(1.41)$ & \\
\hline
\end{tabular}

TABLE 7. Correlation Coefficients Among Independent Variables

\begin{tabular}{lrccrc}
\hline $\begin{array}{l}\text { Independent } \\
\text { Variable }\end{array}$ & $\begin{array}{c}\text { Prior } \\
\text { Dining }\end{array}$ & $\begin{array}{c}\text { Coupon } \\
\text { Value }\end{array}$ & $\begin{array}{l}\text { Coupon } \\
\text { Yes/No }\end{array}$ & Food & Service \\
\hline Prior dining & 1.000 & & & & \\
Coupon value & -0.130 & 1.000 & & & \\
Coupon Yes/No & -0.019 & $0.638^{*}$ & 1.000 & & \\
Food & 0.001 & -0.007 & -0.009 & 1.000 & \\
Service & -0.006 & 0.007 & -0.017 & -0.006 & 1.000 \\
\hline
\end{tabular}

${ }^{*}$ Significant at $p=0.000$ level

Figure 3a-c). Since the horizontal lines representing coupon (vs. no coupon) and the horizontal lines representing different coupon face values intersect in all six profit plots, there is a disordinal interaction effect in all cases. This indicates that the results cannot be interpreted separately from the interaction, but can only be interpreted for each level of prior 
FIGURE 2a-c. Profile Plots of Independent Variables for Coupon Redemption
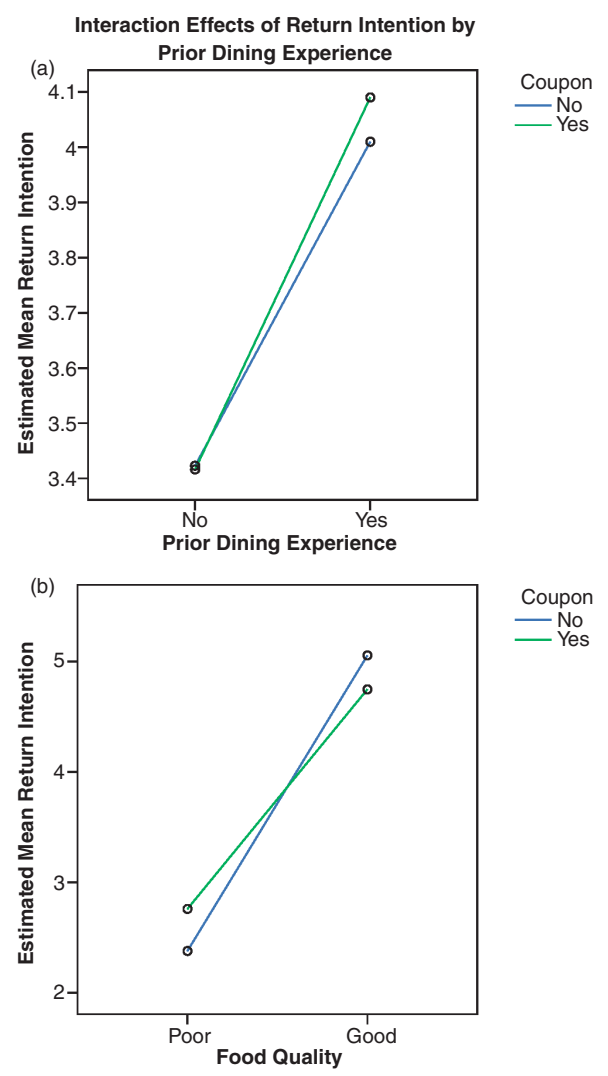

Coupon

二 ${ }^{\mathrm{No}}$

(c)

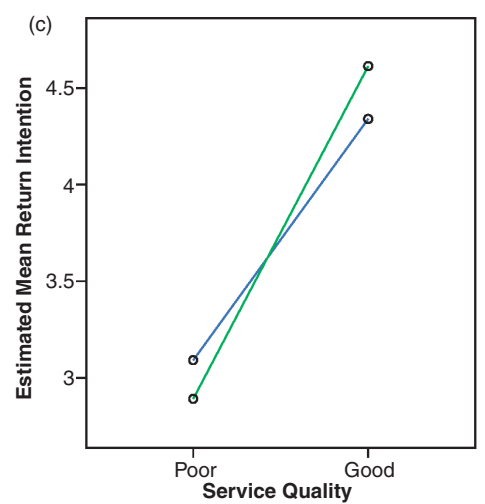

Coupon Z No 
FIGURE 3a-c. Profile Plots of Independent Variables for Coupon Face Value
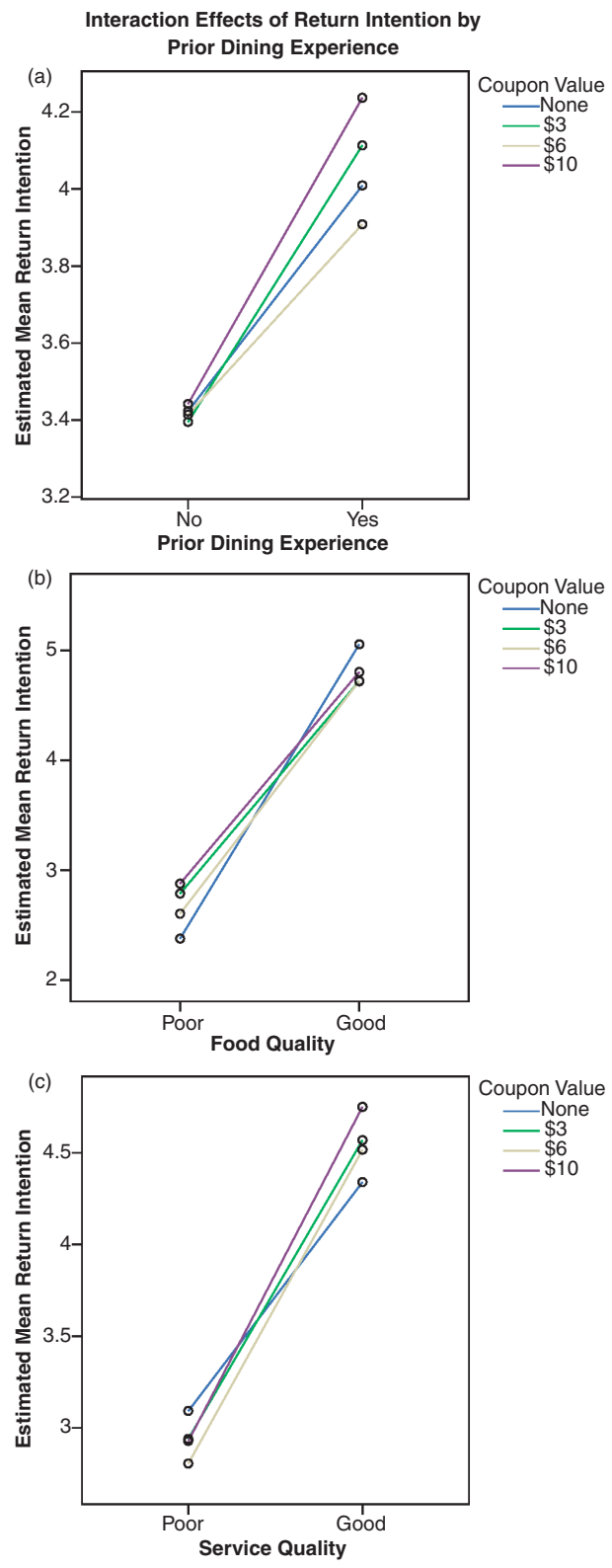
dining, food and service, respectively. The y-axis represents the mean return intention on all six plots and the x-axis represents one of the independent variables (prior dining experience, food quality, and service quality) in each of the plots.

\section{Prior Dining Experience Effect on Return Intention}

The third hypothesis suggests that a customer's prior experience dining at a restaurant will affect his/her return intention. The correlation coefficient for return intention and prior dining (see Table 3 ) is 0.165 $(p=0.000)$, indicating that there is a statistically significant positive relationship between prior dining experience and return intention. Also, as can be seen in the general linear models (see Tables 4 and 5), the main effect of prior dining experience has a positive impact on return intention $(\mathrm{F}=20.19, p=0.000$ and $\mathrm{F}=40.24, p=0.000)$. When comparing the mean return intention of customers (see Table 6) who had prior dining experience (4.08) with those who did not have any prior dining experience in a particular restaurant (3.42), there was a statistically significant difference (see Table 8). This all leads to the support of the third hypothesis which states that after a coupon is redeemed, customers with prior dining experience in a restaurant will be more likely to return to that restaurant than those with no prior dining experience.

\section{Food and Service Quality Effect on Return Intention}

The effect of food and service quality on a customer's return intention has been studied by many other researchers (Lewis, 1981; Ennew \& Binks, 1996; Kivela, 1997; Zeithaml, 2000). They all found that food quality and service quality have resulted in higher repeat purchase. This study meant to hold the quality of food and service constant, to determine

TABLE 8. ANOVA for Return Intention and Prior Dining

\begin{tabular}{lrrrrc}
\hline & \multicolumn{1}{c}{ SS } & df & MS & F & Sig. \\
\hline Between groups & 86.75 & 1 & 86.75 & 22.68 & $0.000^{*}$ \\
Within groups & 3090.02 & 808 & 3.82 & & \\
Total & 3176.77 & 809 & & & \\
\hline
\end{tabular}

*Significant at $p<0.0001$ 
if coupons and prior dining experience affected return intentions of customers. To accomplish this, the researchers indicated to respondents whether the food and service quality at the restaurant at which they dined was good or poor.

Overwhelmingly, customers who had good food reported higher return intentions than those who received poor food (see Table 9). This was also true for those who received good service versus those who received poor service (see Table 10).

Holding food and service constant yielded four different scenarios (see Figure 4). Comparing the mean return intention of the four different groups only yielded one statistically significant difference for customers who used coupons versus those who did not (see Table 11). If

TABLE 9. ANOVA for Return Intention and Food Quality

\begin{tabular}{lrrrrc}
\hline & \multicolumn{1}{c}{ SS } & df & MS & F & Sig. \\
\hline Between groups & 866.34 & 1 & 866.34 & 302.97 & $0.000^{*}$ \\
Within groups & 2310.44 & 808 & 2.86 & & \\
Total & 3176.77 & 809 & & & \\
\hline
\end{tabular}

*Significant at $p<0.0001$

TABLE 10. ANOVA for Return Intention and Service Quality

\begin{tabular}{lrrrrc}
\hline & \multicolumn{1}{c}{ SS } & df & \multicolumn{1}{c}{ MS } & F & \multicolumn{1}{c}{ Sig. } \\
\hline Between groups & 543.16 & 1 & 543.16 & 166.64 & $0.000^{*}$ \\
Within groups & 2633.61 & 808 & 3.26 & & \\
Total & 3176.77 & 809 & & & \\
\hline
\end{tabular}

*Significant at $p<0.0001$

FIGURE 4. Four Food/Service Scenarios

\begin{tabular}{|c|c|c|c|}
\hline \multicolumn{2}{|c|}{ Scenarios } & \multicolumn{2}{c|}{ Food } \\
\cline { 3 - 4 } & Good & Poor \\
\hline \multirow{2}{*}{ Service } & Good & GFGS & PFGS \\
\cline { 2 - 4 } & Poor & GFPS & PFPS \\
\hline
\end{tabular}


TABLE 11. ANOVA for Return Intention Holding Food and Service Quality Constant

\begin{tabular}{|c|c|c|c|c|c|c|c|}
\hline Food 2 & Service 2 & Groups & sS & df & MS & $\mathbf{F}$ & Sig. \\
\hline & & Between & 0.04 & 1 & 0.04 & 0.02 & 0.892 \\
\hline & Poor & Within & 396.29 & 198 & 2.00 & & \\
\hline & & Total & 396.33 & 199 & & & \\
\hline \multirow[t]{6}{*}{ Poor } & & Between & 11.12 & 1 & 11.12 & 4.67 & $0.032^{*}$ \\
\hline & Good & Within & 480.75 & 202 & 2.38 & & \\
\hline & & Total & 491.87 & 203 & & & \\
\hline & & Between & 3.78 & 1 & 3.78 & 1.91 & 0.169 \\
\hline & Poor & Within & 400.71 & 202 & 1.98 & & \\
\hline & & Total & 404.49 & 203 & & & \\
\hline \multirow[t]{3}{*}{ Good } & & Between & 1.03 & 1 & 1.03 & 0.59 & 0.443 \\
\hline & Good & Within & 347.13 & 200 & 1.74 & & \\
\hline & & Total & 348.16 & 201 & & & \\
\hline
\end{tabular}

*Significant at $p<0.05$

customers received poor food and good service, those customers who used a coupon had a higher return intention (3.25) than those who did not use a coupon (2.59) (see Table 6). This indicates that service quality is a more significant contributor to return intention than food quality.

\section{DISCUSSION AND IMPLICATIONS}

The findings of this study revealed that redemption of a coupon did not affect return intention to a restaurant. Also, the face value of the coupon did not affect return intention to a particular restaurant. A high coupon face value did not more greatly influence return intention compared with a lower coupon face value. This finding runs counter to the findings of previous studies in consumer goods where high face value coupons decrease the probability of repeat purchase (Bawa \& Showemaker, 1987; Showemaker \& Tibrewala, 1985; Irons et al., 1984). The findings of this study imply that unlike consumer goods, the quality of food and service are better indicators of return intention than coupon use or face value. Therefore, employing a coupon strategy may fail to retain these customers if the restaurant does not meet customers' expectations in terms of food and service quality when they use the coupon. 
Second, the study demonstrates the importance of building a relationship with repeat customers. Numerous hypothetical situations were created in order to measure return intention of repeat and new customers while controlling factors that might explain true return intention. As would be expected, repeat customers showed greater continued support of the restaurant than new customers. In fact, respondents with prior dining experience showed higher return intention in every manipulated condition compared with those with no prior dining experience, even in a situation in which they perceived the quality of food and service to be poor.

This finding was consistent with previous research that suggests repeat customers are more likely to purchase again after the promotion has ended (Taylor \& Long-Tolbert, 2002; Taylor, 2001; Bawa \& Shoemaker, 1989; Shoemaker \& Shoaf, 1977). It appears that repeat customers have already established a strong perception of food and service quality in that establishment; a coupon may serve as a reward to enhance their positive attitude toward the restaurant (Blattberg \& Neslin, 1990, p. 270); therefore, they showed higher return intention than that of new customers regardless of whether or not they redeemed a coupon. This view is consistent with previous studies (e.g., Taylor \& LongTolbert, 2002) that suggest that repeat customers view coupons as rewards and reminders that encourage them to return to a regular buying pattern.

Finally, the impact that food and service quality have on return intention was confirmed. In fact, respondents reported that the quality of food and service were key determinants in making their return decisions. Previous studies (e.g., Koo, Tao, \& Yeung, 1999) suggest that the quality of food and service are the most important factors in selecting a restaurant. Our study suggests that restaurateurs should recognize that a coupon can be a temporary promotional device that attracts new customers but retaining them depends on meeting their expectations of food and service quality.

\section{SUMMARY AND CONCLUSION}

The goal of coupon promotion is to build up purchase frequency (Blattberg \& Neslin, 1990, p. 271). This study examined the effects of coupon promotion on return visits in restaurants if a customer redeemed 
a coupon. Specifically, the likelihood of return visits after a coupon is redeemed and the factors that influence customers to return were evaluated. The study found that repeat customers showed a higher likelihood of return than new customers, regardless of the food and service quality received. The study also showed that the quality of food and service were critical indicators of return intention. However, contrary to findings in consumer goods studies, the findings of this study demonstrated that the redemption of coupons, regardless of face value, did not influence the likelihood of return.

This study had some limitations. First, it used student samples. Student samples may not accurately represent the true population being studied; however, the students in this study indicated that they dine out on average 1-3 times per week and spend an average of $\$ 11-\$ 20$ per meal per person when they do dine out. The students in this sample also indicated that their average annual household income was over $\$ 30,000$. Students at this university tend to work at least part time while attending school and many work full time. Bearing this in mind, the results may not be generalizable to the population of all restaurant customers. Also, the age range of this sample is limited to potential customers in their twenties. It is possible that different age groups may respond to coupon promotions differently from this sample. Another limitation is that written, hypothetical scenarios were used instead of sampling customers in a real restaurant.

These limitations offer opportunities for further research. Further research might test the hypotheses used in this study in real restaurant settings. Different age groups, especially baby boomers, can be tested as to whether their return intention with coupon promotions would be similar to the samples from this study. Identifying the perceptions of coupon promotion with different segments of customers would be helpful to restaurateurs when they are developing coupon promotion strategies based on their target customers. Also, different coupon face values (e.g., half-price or free meals) can be used to test the sensitivity of customers to larger promotional coupons.

Despite its limitations, the findings of this study provide important insight for restaurateurs in understanding the effects of coupon promotion. First, restaurateurs should be aware of the danger of employing a coupon strategy that only relies on face values to attract new customers. The findings suggest that coupon face value was not an important factor for most customers. Restaurants may attract both new and repeat customers with 
higher value coupons; however, maintaining and enhancing repeat purchase were dependent on meeting customers' expectations in terms of food and service quality. Second, as previous studies (e.g., Taylor \& Long-Tolbert, 2002) suggest, restaurateurs should develop a coupon promotion strategy to maintain and enhance long-term relationships with their repeat customers. The findings of this study show that repeat customers showed higher return intentions than new customers regardless of coupon face value and food and service quality. One might ask why restaurants offer coupons to repeat customers who may come back regardless of whether or not they have a coupon. However, repeat customers are a major source of revenue for most restaurants (Taylor \& Long-Tolbert, 2002). Offering a coupon as a token of appreciation for supporting the business can result in a more positive attitude toward the restaurant. This group's revenue generation may eventually offset the cost of temporary coupon promotions (Taylor \& Long-Tolbert, 2002).

Although this study is subject to several limitations, we believe that the findings of the study will help restaurateurs identify the factors that encourage customers to return to their establishments, understand what factors contribute to forming a long-term relationship with their customers, and, therefore, develop successful coupon promotion strategies to increase profits.

\section{REFERENCES}

Bawa, K. \& Shoemaker, R. W. (1987). The effects of a direct mail coupon on brand choice behavior. Journal of Marketing Research, 24, 37-376.

Bawa, K. \& Shoemaker, R. W. (1989). Analyzing incremental sales from a direct mail coupon promotion. Journal of Marketing, 53, 66-78.

Bebko, C. P. (2000). Service intangibility and its impact on consumer expectations of service quality. Journal of Services Marketing, 14 (1), 9-26.

Blattberg, R. C. \& Neslin, S. A. (1990). Sales promotion: Concept, methods, and strategies. Englewood Cliff, NJ: Prentice Hall.

Cheong, K. J. (1993). Observations: Are cents-off coupons effective? Journal of Advertising Research, 73-78.

Dodson, J. A., Tybout, A. M., \& Sternthal, B. (1978). Impact of deals and deal retraction on brand switching. Journal of Marketing Research, XV, 72-81.

Ehrenberg, A. S. C., Hammond, K., \& Goodhardt, G. J. (1994). The after-effects of price-related consumer promotions. Journal of Advertising Research, 11-21.

Ennew, C. T. \& Binks, M. R. (1996). The impact of service quality and service characteristics on consumer retention: Small business and their banks in the U.K. British Journal of Management, 7(3), 219-230. 
Garretson, J. \& Chow, K. (1999). The influence of coupon face value on service quality expectations, risk perceptions and purchase intentions in the dental industry. Journal of Services Marketing, 13(1), 59-72.

Irons, K., Little, J., \& Klein, R. (1984). Determinants of coupon effectiveness. Advances and Practices of Marketing Science. Proceedings of the 1983 ORSA/TIMS marketing Science Conference (March), 157-164.

Kivela, J. J. (1997). Restaurant marketing: Selection and segmentation in Hong Kong. International Journal of Contemporary Hospitality Management, 9(3), 116-123.

Koo, L. C., Tao, F. K. C., \& Yeung, J. H. C. (1999). Preferential segmentation of restaurant attributes through conjoint analysis. International Journal of Contemporary Hospitality Management, 11(5), 242-253.

Krishna, A. \& Shoemaker, R. W. (1992). Estimating the effects of higher coupon face values on the timing of redemption, the mix of coupon redeemers, and purchase quantity. Psychology \& Marketing, 9(6), 453-468.

Lewis, R. (1981). Restaurant advertising: Appeals and customers' intentions. Journal of Advertising Research, 21(5), 69-74.

Perlik, A. (2002). Let's make a deal. Restaurant and Institutions, 112(20), 57-61.

Pointer, L. V. (2000). Consumers' coupon use behavior: A theory of planned behavior perspective. (Doctoral dissertation, Texas A \& M University, 2000).

Shoemaker, R. W. \& Shoaf, F. R. (1977). Repeat rates of deal purchase. Journal of Advertising Research, 17(2), 47-53.

Shoemaker, R. \& Tibrewala, V. (1985). Relating coupon redemption rates to past purchasing of the brand. Journal of Advertising Research, 25(5), 40-47.

Taylor, G. A. (2001). Coupon response in service. Journal of Retailing, 77, 139-151.

Taylor, G. A. \& Long-Tolbert, S. (2002). Coupon promotion in quick-service restaurants: Preaching to the converted? The Cornell Hotel and Restaurant Administration Quarterly, 43(4), 41-47.

Varadarajan, R. P. (1984). Consumer responses to small business coupon sales promotions. American Journal of Small Business, IX(2), 17-26.

Zeithaml, V. A. (2000). Service quality, profitability, and the economic worth of customers: What we know and what we need to learn. Journal of the Academy of Marketing Science, 28(1), 67-85.

doi:10.1300/J369v09n01_05 